\title{
Spleen tyrosine kinase inhibition in the treatment of autoimmune, allergic and autoinflammatory diseases
}

\author{
Omer N Pamuk, ${ }^{1,2}$ and George C Tsokos ${ }^{* 1}$
}

\begin{abstract}
Spleen tyrosine kinase (Syk) is involved in the development of the adaptive immune system and has been recognized as being important in the function of additional cell types, including platelets, phagocytes, fibroblasts, and osteoclasts, and in the generation of the inflammasome. Preclinical studies presented compelling evidence that Syk inhibition may have therapeutic value in the treatment of rheumatoid arthritis and other forms of arthritis, systemic lupus erythematosus, autoimmune cytopenias, and allergic and autoinflammatory diseases. In addition, Syk inhibition may have a place in limiting tissue injury associated with organ transplant and revascularization procedures. Clinical trials have documented exciting success in the treatment of patients with rheumatoid arthritis, autoimmune cytopenias, and allergic rhinitis. While the extent and severity of side effects appear to be limited so far, larger studies will unravel the risk involved with the clinical benefit.
\end{abstract}

\section{Introduction}

Spleen tyrosine kinase (Syk) is a cytoplasmic tyrosine kinase of $72 \mathrm{kDa}$ and a member of the ZAP70 ( $\zeta$-chainassociated protein kinase of $70 \mathrm{kDa}$ )/Syk family of the non-receptor-type protein tyrosine kinases (PTKs) [1,2] and contains two SRC homology 2 (SH2) domains and a kinase domain [3]. Syk is expressed in most hematopoietic cells, including $B$ cells, immature $T$ cells, mast cells, neutrophils, macrophages, and platelets $[1,3,4]$, and is important in signal transduction in these cells $[2,5]$.

*Correspondence: gtsokos@bidmcharvardedu

'Division of Rheumatology, Beth Israel Deaconess Medical Center, Harvard Medical School, 330 Brookline Avenue, CLS-928, Boston, MA 02115, USA

Full list of author information is available at the end of the article
Syk plays an important role in signal transduction initiated by the classic immunoreceptors, including B-cell receptors (BCRs), Fc receptors, and the activating natural killer receptors [3,6,7]. Syk is associated mainly with ITAM (immunoreceptor tyrosine-based activation motif)dependent pathways and affects early development and activation of B cells, mast cell degranulation, neutrophil and macrophage phagocytosis, and platelet activation $[1,3,4]$. Functional abnormalities of these cells are invariably associated with both autoimmune and allergic diseases. Although there have been many exciting developments in the treatment of these diseases, there are still serious limitations of the efficacy of the used drugs as they are associated with the development of serious side effects. Because of the central role of Syk in signaling processes not only in cells of the adaptive immune response but also in additional cell types known to be involved in the expression of tissue pathology in autoimmune, autoinflammatory, and allergic diseases, Syk inhibition has attracted considerable interest for further development. In this review, we will provide a brief account of the role of Syk signaling in various cell types and will summarize preclinical and clinical studies, which point to the therapeutic usefulness of Syk inhibition.

\section{Syk in cell function}

\subsection{Syk and lymphocytes}

The function of Src-family kinases and Syk kinases in immunoreceptor signaling pathways is well known (Figure 1) [6]. After receptor engagement, Src-family kinases phosphorylate the ITAMs of immunoreceptors and this results in the recruitment and activation of Syk [6,7]. BCR- and FcR-defined dual-phosphorylated ITAMs recruit Syk through interaction with their tandem SH2 domains, and this triggers kinase activation and downstream signaling $[4,8]$.

Because the development of $\mathrm{B}$ and $\mathrm{T}$ cells requires intact antigen receptor-mediated signal transduction, Syk deficiency leads to a complete absence of mature B cells, and ZAP70 deficiency results in severe T-cell defects 


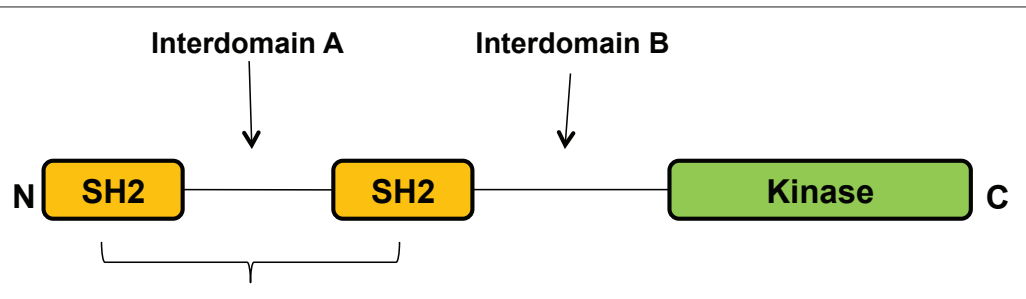

ITAM-binding region

Figure 1. Structure of spleen tyrosine kinase (Syk) protein. Syk includes two tandem SH2 domains and a tyrosine kinase domain. Interdomain A is between the two SH2 domains, and interdomain B is between the tyrosine kinase domain and C-terminal SH2 domain. ITAM, immunoreceptor tyrosine-based activation motif; SH2, Src homology 2.

$[9,10]$. Syk plays an important role in the transition of pro-B cells into pre-B cells [9]. Although it was previously thought that BCR signaling was mediated via Syk and T-cell receptor (TCR) signaling via ZAP70, recent data have shown that ZAP70 has a role in B-cell development and Syk is important in pre-T cell signaling (Figure 2) $[11,12]$. It appears that Syk and ZAP70 have overlapping roles in early lymphocyte development $[11,12]$.

For the transmission of BCR-mediated cell signaling events, subsequent activation of different types of PTKs, including Syk, is required [13]. BCR aggregation can directly stimulate activation of pre-associated Syk, resulting in tyrosine phosphorylation of $\operatorname{Ig} \alpha$-Ig $\beta$ ITAMs $[6,14,15]$. This phosphorylation leads to recruitment of additional Syk. Subsequently, recruited Syk is activated by Src-PTK-dependent transphosphorylation and by autophosphorylation $[6,14]$. Therefore, Syk is necessary for BCR-mediated tyrosine phosphorylation and signal transduction $[6,15]$.

\subsection{Syk and phagocytes}

$\mathrm{Fc} \gamma \mathrm{R}$, one of the classic immunoreceptors, typically engages Syk $[3,7,16,17]$, and Syk-deficient murine macrophages display defective phagocytosis $[7,16]$. After Fc $\gamma R$ engagement, ITAMs in the receptor are phosphorylated by Src-family kinases, resulting in the recruitment and activation of Syk. As a result, Syk-mediated phosphorylation of several adaptor proteins causes activation of downstream pathways, which execute phagocytosis. Syk is also important in complement-mediated phagocytosis resulting from the binding of C3bi-coated particles to complement receptor $3[3,17]$. Downstream of Syk, the signal involves Vav and RhoA to generate contractile forces, which result in the engulfment of the phagocytosed particles $[3,17,18]$.

\subsection{Syk and mast cells}

FceRI, the high-affinity surface receptor for IgE, is expressed on the surface membrane of mast cells, and crosslinking of receptor-bound $\operatorname{IgE}$ by multivalent antigen starts the activation of mast cells by promoting the aggregation of FceRI [19,20]. Degranulation and cytokine release occur after the activation signal starts the cascade [20]. These events contribute to the development and continuation of allergic inflammation. Syk plays an important role in the development of signal transduction events initiated after FceRI aggregation $[2,21]$, mast cell activation, degranulation, and cytokine production (Figure 3) [22,23]. All of these facts point to the conclusion that Syk inhibition might be an attractive target for preventing allergen-induced diseases.

\subsection{Syk and platelets}

There are three platelet surface molecules, which, upon engagement, initiate Syk-mediated activation of SLP76 (SH2 domain-containing leukocyte proteins 76) and phospholipase C 2 (Figure 4) [24,25]: (a) Platelet/megacaryocyte lineage cells express the platelet-specific integrin $\alpha \operatorname{IIb} \beta 3$ on their surface and this is required for normal hemostasis [3]. Syk mediates outside-in signaling by $\alpha \operatorname{IIb} \beta 3$ integrin on platelets [26,27]. The mechanism of Syk activation by $\alpha \operatorname{Ib} \beta 3$ integrin was reported to require the ITAM-containing FcyIIA molecule [26]. (b) Glycoprotein VI (GPVI), a major collagen receptor of platelets, is an Fc $\gamma R$-related receptor and is closely associated with FcaRs [24]. Collagen activates the Fc $\gamma R$-associated receptor GPVI on platelets and triggers Syk activation in an ITAMdependent way $[24,28]$. SLP76, a Syk substrate, is required for arterial thrombus formation [28]. (c) Platelet agonists like rhodocytin and podoplanine activate the receptor Ctype lectin-like receptor 2 (CLEC2), which recruits Syk to the phosphorylated tyrosine in the CLEC2 ITAMs $[4,28]$.

\subsection{Syk in vascular development}

Syk is required for the separation of lymphatic vessels in the general circulation $[9,29]$. Syk-deficient mice die because blood fills the lymphatic vessels [29]. Probably, Syk activation together with platelet activation and aggregation play a role in lymphatic vessel development and their separation from blood vessels $[4,9]$. 

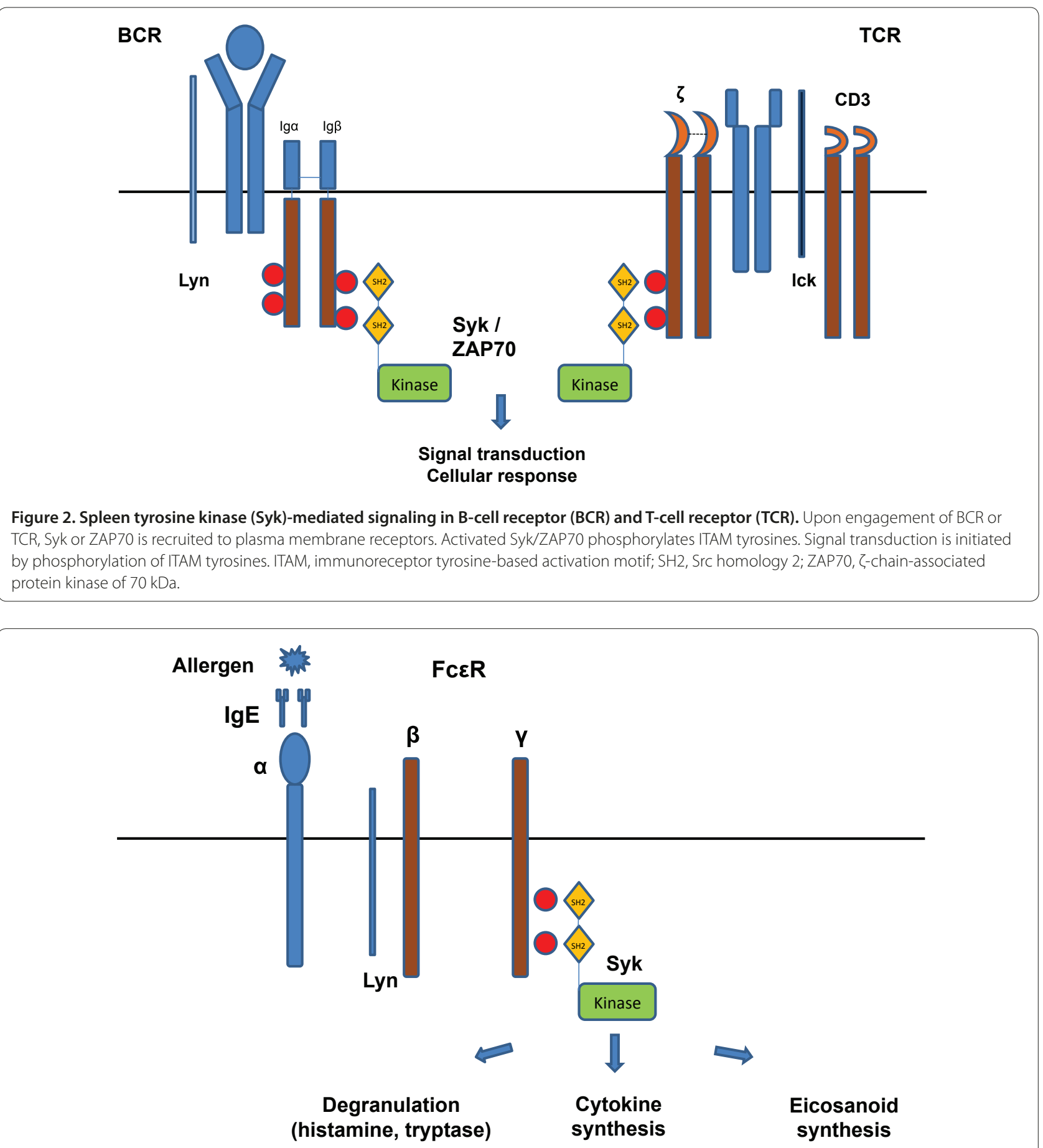

Figure 3. FcعR crosslinking by allergen involves spleen tyrosine kinase (Syk)-mediated signaling transduction. Allergen binding to lgE bound to FceR on mast cell initiates Lyn phosphorylation of the receptor and activation of Syk. Signaling events lead to mast cell degranulation, eicosanoid mediator synthesis, and cytokine production. FceR, Fc receptor $\varepsilon$-chain; SH2, Src homology 2.

\subsection{Syk and osteoclasts}

Osteoclasts are multinucleated cells that degrade bone by releasing proper enzymes. Syk has been claimed to have a role in osteoclast differentiation and osteoclast function [3,4]. Although $F c \gamma R$ is associated with osteoblast-osteoclast interactions, DAP12 (DNAXactivating protein of molecular mass $12 \mathrm{kDa}$ ) is the responsible protein for relaying an osteoblastindependent signal $[30,31]$. Syk, which is downstream of DAP12 and Fc $\gamma$ R, is required for osteoclast development 

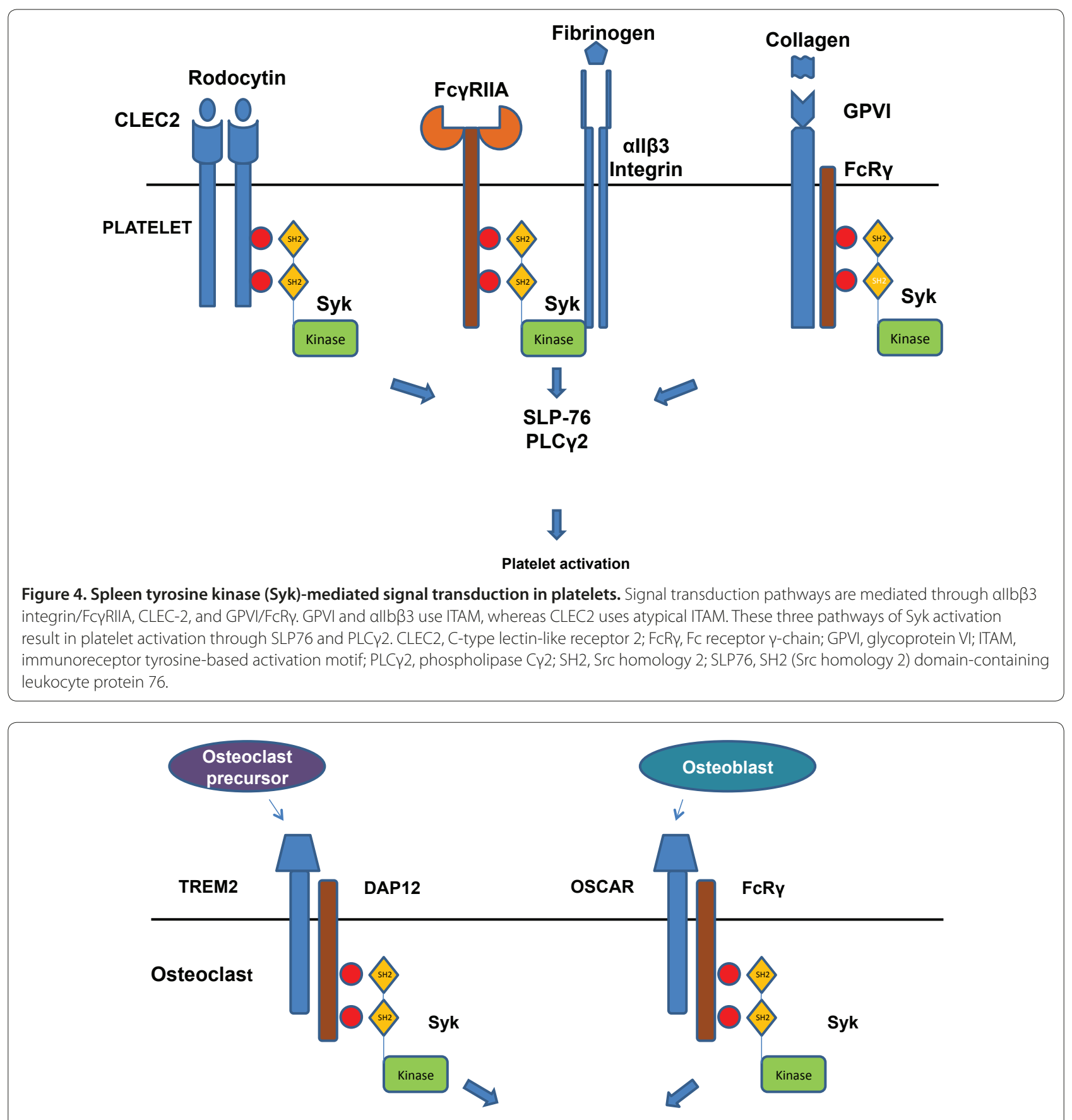

PLCY2 activation, Ca signaling

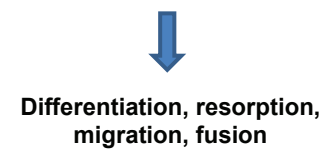

Figure 5. Model of the role of spleen tyrosine kinase (Syk) in osteoclastogenesis. Osteoclast differentiation and function are stimulated by signals from ITAM-bearing adapter chains. DAP12 associates with TREM2, and similarly OSCAR associates with FcyR chain. After ligation of the extracellular domain of the receptor, DAP12 or FCRy is tyrosine-phosphorylated by Syk. Activation of Syk initiates a number of signaling events. DAP12, DNAX-activating protein of molecular mass $12 \mathrm{kDa}$; FCR $\gamma$, Fc receptor $\gamma$-chain; ITAM, immunoreceptor tyrosine-based activation motif; OSCAR, osteoclast-specific activating receptor; PLCY2, phospholipase C $Y 2$; SH2, Src homology 2; TREM2, triggering receptor expressed on myeloid cells. 
and function (Figure 5) [30,32]. DAP12 phosphorylation recruits Syk through its $\mathrm{SH} 2$ domain, leading to autophosphorylation. Phosphorylated Syk associates with cytoskeleton network and actin ring formation [3]. In addition, it was reported that Syk plays a role in the process of osteolysis. Syk, therefore, represents an attractive therapeutic target to mitigate increased osteoclastic activity in arthritis.

\subsection{Syk and fibroblasts}

Fibroblast-like synoviocytes (FLSs) represent a significant component of the synovial lining and contribute to the lubrication and preservation of the joint. In rheumatoid arthritis (RA), FLSs expand in numbers, acquire immune cell features, produce proinflammatory cytokines and enzymes, and contribute to the inflammatory process and the eventual destruction of the joint. A number of studies have claimed a role for Syk in the function of FLSs $[33,34]$. Syk activation is important in tumor necrosis factor-alpha (TNFo)-induced cytokine and metalloproteinase (MMP) production by RA FLSs [33]. Syk also plays an important role in TNF $\alpha$-induced c-Jun Nterminal kinase (JNK) activation in FLSs [33]. This is an important event as in the future Syk inhibition may be used to supplement the therapeutic effect of TNF inhibition in patients who do not display sufficient response to TNF blockade. Activation of Syk by TNF $\alpha$ causes the activation of the protein kinase C $\delta / J N K / c-J u n$ signaling pathway and this is important for the secretion of a critical cytokine, interleukin-32 (IL-32), by RA FLSs [34].

\section{Syk inhibition therapy in autoimmune and allergic inflammatory diseases}

Although the exact mechanisms of action remain unclear, Syk inhibitors have claimed encouraging therapeutic results in the treatment of patients with allergy, autoimmune diseases, or B-cell lineage malignancies $[23,35,36]$. R406, an orally available active metabolite of the prodrug R788 (fostamatinib), is a competitive Syk inhibitor [37,38]. The selectivity for R406 in inhibiting Syk is limited as it may inhibit additional kinases and non-kinase targets. Among those targets are FMS-related tyrosine kinases 3 (FLT3), Lck, and Janus kinase 1 (JAK1) and JAK3, which may also be involved in the expression of autoimmune pathology [4]. These non-Syk targets may enhance the clinical value of R406 in the treatment of autoimmune diseases as JAK inhibitors have been considered for the treatment of arthritis. R112 is another Syk inhibitor formulated for intranasal use [39] and has a rapid effect and quickly inhibits mast cell activation. Additional Syk inhibitors with less specificity include piceatannol and BAY 61-3606 [40,41].

\subsection{Syk inhibition in arthritis}

Despite enormous advances in the treatment of RA, a significant number of patients either fail to respond to treatment or develop significant side effects. Based on a number of laboratory findings and preclinical studies, including the fact that RA synovium displays increased amounts of phosphorylated Syk compared with osteoarthritis synovium [33], significant effort is currently being devoted to determine whether Syk inhibition can be used to treat patients with RA (Table 1).

\subsubsection{Animal arthritis models and Syk inhibition}

Strong preclinical studies point to the therapeutic potential of Syk inhibition. Syk-deficient bone marrow murine chimeras do not allow the development of arthritis following the injection of arthritogenic $\mathrm{K} / \mathrm{BxN}$ serum [42], suggesting the importance of hematopoietic cell Syk-dependent signaling in the development of arthritis. Administration of R406 reduced clinical arthritis in two antibody-induced arthritis models (K/BXN serum and collagen antibody). In addition, R406 suppressed bone erosions detected by radiography, pannus formation, and synovitis in these animal models [37]. It was also observed that the expression of Syk in synovial tissues correlated with the levels of inflammatory cell infiltrates in the joints and was virtually undetectable in R406treated mice subjected to collagen-induced arthritis in rats [38]. In addition, Syk inhibition reduced synovial fluid cytokine levels and cartilage oligomeric matrix protein in serum in these animals [38]. R406 was also found to limit an Arthus reaction in mice [37] and rats [38] and reverse passive Arthus reaction in murine chimeras with Syk-deficient hematopoietic cells [43,44]. This effect is probably due to the suppression of immunecomplex-mediated inflammation by inhibiting the Fc receptor signaling.

\subsubsection{Human studies}

After a small phase I study [45] in which clinical efficacy of the R788 Syk inhibitor in patients with RA was not associated with serious side effects, a 12-week, randomized, placebo-controlled trial in which active RA patients who were also receiving methotrexate (MTX) were enrolled was carried out [46]. Twice-daily oral doses of 100 and $150 \mathrm{mg}$ of R788 were demonstrated to be significantly superior to placebo and $50 \mathrm{mg}$ twice a day of R788. Interestingly, the clinical effect was noted as early as 1 week after the initiation of treatment. Patients receiving 100 and $150 \mathrm{mg}$ R788 achieved excellent ACR20 (American College of Rheumatology 20\% improvement criteria) (65, 72\%), ACR50 (49, 57\%), and ACR70 (33, $40 \%)$ responses. Also, significant reductions in serum IL-6 and MMP-3 levels were noted within the first week of treatment. Diarrhea and other gastrointestinal adverse 
Table 1. Spleen tyrosine kinase inhibition therapy in arthritis animal models and patients with rheumatoid arthritis

\begin{tabular}{|c|c|c|c|c|}
\hline Reference & Drug & Duration & Model or disease & Outcome \\
\hline $\begin{array}{l}\text { Braselmann } \\
\text { et al. [37] }\end{array}$ & R406 & $\begin{array}{l}14 \text { days, twice } \\
\text { a day, orally }\end{array}$ & $\begin{array}{l}\text { Collagen-induced arthritis, K/BXN } \\
\text { arthritis model }\end{array}$ & Improved clinical scores, histopathology, and radiography \\
\hline $\begin{array}{l}\text { Pine et al. } \\
{[38]}\end{array}$ & R406 & $\begin{array}{l}18 \text { days, twice } \\
\text { a day, orally }\end{array}$ & Collagen-induced arthritis in rats & $\begin{array}{l}\text { Suppressed clinical arthritis, bone erosions, pannus } \\
\text { formation, and synovitis }\end{array}$ \\
\hline $\begin{array}{l}\text { Weinblatt } \\
\text { et al. [46] }\end{array}$ & R406 & $\begin{array}{l}12 \text { weeks, } 100 \text { or } \\
150 \text { mg twice a day, } \\
\text { orally }\end{array}$ & $\begin{array}{l}\text { Active RA patients who were } \\
\text { incomplete responders to MTX }\end{array}$ & $\begin{array}{l}\text { R788 (100 mg twice a day): } \\
\text { ACR20, } 50 \text {, and } 70 \text { responses (65\%, 49\%, and 33\%) } \\
\text { R788 (150 mg every day): } \\
\text { ACR20, } 50 \text {, and } 70 \text { responses }(72 \%, 57 \% \text {, and } 40 \%)\end{array}$ \\
\hline $\begin{array}{l}\text { Weinblatt } \\
\text { et al. [47] }\end{array}$ & R788 & $\begin{array}{l}6 \text { months, } 100 \text { or } \\
150 \text { mg twice a day, } \\
\text { orally }\end{array}$ & $\begin{array}{l}\text { Active RA patients who were } \\
\text { incomplete responders to MTX }\end{array}$ & $\begin{array}{l}\text { R788 (100 mg twice a day): } \\
\text { ACR20, } 50 \text {, and } 70 \text { responses ( } 66 \%, 43 \% \text {, and } 28 \%) \\
\text { R788 (150 mg every day): } \\
\text { ACR20, } 50 \text {, and } 70 \text { responses }(57 \%, 32 \% \text {, and } 14 \%)\end{array}$ \\
\hline $\begin{array}{l}\text { Genovese } \\
\text { et al. [48] }\end{array}$ & R788 & $\begin{array}{l}3 \text { months, } 100 \mathrm{mg} \\
\text { twice a day, orally }\end{array}$ & $\begin{array}{l}\text { Active RA patients who failed } \\
\text { biologic agents }\end{array}$ & $\begin{array}{l}\text { R788 (100 mg twice a day): } \\
\text { ACR20 response ( } 39 \%) \text {. } \\
\text { Response rate was not different from that of placebo. }\end{array}$ \\
\hline
\end{tabular}

ACR20, American College of Rheumatology 20\% improvement criteria; ACR50, American College of Rheumatology 50\% improvement criteria; ACR70, American College of Rheumatology 70\% improvement criteria; MTX, methotrexate; RA, rheumatoid arthritis.

effects such as nausea and gastritis, neutropenia, and elevation in transaminase level were the reported major side effects.

In the follow-up study, 100 and $150 \mathrm{mg}$ (twice daily) of R788 were compared with placebo at 6 months in 457 active RA patients who were MTX incomplete responders [47]. The ACR20 response was achieved in 66\% and $57 \%$ of patients in the 100 and $150 \mathrm{mg}$ groups, respectively, compared with $35 \%$ in the placebo group. Both R788 dosing regimens achieved statistical significance compared with placebo at the sixth month. In this study, the onset of clinical effect was again rapid with maximum improvement achieved by week 6 and maintained throughout the study. The most common side effect was reversible and dose-dependent diarrhea. Transient neutropenia, hypertension, and elevation of liver function tests were also recorded.

Another randomized placebo-controlled phase II study was conducted in 219 RA patients who had failed treatment with at least one biologic agent [48]. Patients received either $100 \mathrm{mg}$ (twice daily) of R788 or placebo. ACR20 response and magnetic resonance imaging (MRI) images of the hands and wrists were evaluated 3 months later. There was no statistical difference in the ACR20 response between the two groups. However, a significant decrease in erythrocyte sedimentation rate and C-reactive protein and improvement in synovitis and osteitis scores on MRI were observed in the R788 group compared with the placebo group.

\subsection{Syk inhibition in lupus animal models}

In systemic lupus erythematosus (SLE), the FcyR-Syk associates with the TCR in lieu of the zeta-chain ZAP70 [49]. This rewiring of the TCR has been claimed to account, at least partly, for the overactive T-cell phenotype observed in SLE [35]. In addition, the pathogenesis of SLE has been associated with B-cell activation in which Syk may play an important role. Therefore, Syk inhibition therapy was used in lupus animal models (Table 2).

Long-term (24 to 34 weeks) administration of R788 to lupus-prone NZB/NZW mice before and after disease onset [50] resulted in delayed onset of proteinuria and renal dysfunction, decreased kidney infiltrates, and prolonged survival in these mice. Although antibody titers were minimally affected, a dose-dependent reduction in the numbers of $\mathrm{CD}^{+}$activated $\mathrm{T}$ cells expressing high levels of CD44 or CD69 in spleens from R788treated mice was noted. Arthus responses were also reduced in NZB/NZW mice pretreated with R788. Also, a Syk inhibitor was reported to reduce the severity of established antibody-mediated experimental glomerulonephritis in rats [51].

Treatment of lupus-prone MRL/lpr and BAX/BAK mice with R788 not only prevented the development of skin and renal pathology but also treated established disease [52]. Syk inhibition reduced splenomegaly and lymphadenopathy and other immune parameters. The fact that Syk inhibition suppresses SLE in at least three lupus-prone mice suggests that Syk inhibition in patients with SLE may be of clinical value.

\subsection{Syk inhibition in allergic diseases}

Mainstay therapy for allergic diseases remains avoidance of allergens and allergen-specific immunotherapy [23]. However, allergen avoidance and immunomodulation therapies are usually impractical, complex, and timeconsuming [23]. Targeting activation of mast cells to prevent release of mediators represents an important treatment alternative $[20,39,52,53]$. An effective way to inhibit the production and release of all mast cell 
Table 2. Spleen tyrosine kinase inhibition therapy in lupus animal models

\begin{tabular}{lllll}
\hline Reference & Drug & Duration & Model & Outcome \\
\hline Bahjat et al. [50] & R788 & $\begin{array}{l}24 \text { to } 34 \text { weeks, 20 to } \\
40 \mathrm{mg} / \mathrm{kg} \text { twice daily, } \\
\text { orally }\end{array}$ & Lupus-prone mice (NZB/NZW) & $\begin{array}{l}\text { Delayed proteinuria and kidney dysfunction and prolonged } \\
\text { survival }\end{array}$ \\
$\begin{array}{llll}\text { Deng to } 10 \mathrm{~g} / \mathrm{kg} \text { of diet, [52] } \\
\text { up to 16 weeks, orally }\end{array}$ & $\begin{array}{l}\text { R788 } \\
\text { BAX/BAK) }\end{array}$ & $\begin{array}{l}\text { Decreased skin and renal disease } \\
\end{array}$
\end{tabular}

mediators should aim at interfering with the action of $\operatorname{IgE}$ by blocking the FcR $\varepsilon$ with biologics [20,23]. Alternatively, targeting the intracellular signaling cascade may represent an attractive approach. Appropriately, protein tyrosine kinases such as Syk, Lyn, and Btk have been directly implicated in IgE-dependent mast cell activation and have been suggested as targets for therapeutic intervention [39-41]. Syk represents the most attractive target because studies with mast cells derived from Sykdeficient indicated mice showed that Syk is important in the activation of mediators of degranulation, eicosanoid, and cytokine production $[23,39]$. Syk inhibition therapies in allergic diseases are summarized in Table 3.

\subsubsection{Animal allergic disease models and Syk inhibition}

Seow and colleagues [40] examined the effect of piceatannol, a Syk inhibitor, on ovalbumin-induced anaphylactic contraction of isolated guinea pig bronchi and release of histamine and peptidoleuketrienes in vitro. Piceatannol pretreatment slightly suppressed peak anaphylactic bronchial contraction but facilitated relaxation of the contracted bronchi. Piceatannol did not inhibit direct histamine-, leukotriene D4-, or $\mathrm{KCl}$-induced bronchial contraction or revert an existing anaphylactic bronchial contraction but did significantly prevent ovalbumininduced release of both histamine and peptidoleukotrienes from lung fragments. But piceatannol did not inhibit exogenous arachidonic acid-induced release of peptidoleukotrienes from lung fragments. In an antigeninduced airway inflammation model in rodents, the Syk inhibitor BAY 61-3606 blocked both degranulation and lipid mediator and cytokine synthesis in mast cells and suppressed antigen-induced passive coetaneous reaction, bronchoconstriction, bronchial edema, and airway inflammation [41].

R406 inhibited pulmonary eosinophlia, goblet cell metaplasia, and airway hyper-responsiveness (AHR), which developed in BALB/c mice exposed to aerosolized $1 \%$ ovalbumin for 10 consecutive days [20]. In addition, treatment with R406 suppressed the presence of eosinophils and lymphocytes and IL-13 in bronchoalveolar lavage fluid. Suppression of Syk in bone marrow-derived dendritic cells was considered important in the suppression of AHR. This preclinical information has justified attempts to determine whether Syk inhibition may have clinical value.

\subsubsection{Human allergic diseases and Syk inhibition}

Syk inhibition has tried in patients suffering of allergic disorders to determine whether it mitigates clinical manifestations. A nasal allergen challenge study in volunteers with allergic rhinitis showed that one intranasal dose of R112 is clinically safe and significantly reduces the level of prostaglandin D2, a key mediator of allergic nasal congestion, but not histamine and tryptamine levels [54]. In this 2-day, multiple-dose, double-blind, placebo-controlled clinical study with seasonal allergic rhinitis patients, R112 significantly decreased the global clinical symptom score compared with placebo. Each individual symptom, like sneezing, stuffiness, itching, runny nose, cough, postnasal drip, facial pain, and headache, was also significantly improved in the R112 group compared with control treatment. The most important feature of $\mathrm{R} 112$ was noted to be the rapid onset of action. Within 45 minutes, rhinitis symptoms were relieved by using R112, and the duration of action extended to 4 hours. It appears that larger studies to validate the efficacy of Syk inhibition in the treatment of allergy are in order.

\subsection{Syk inhibition in immune thrombocytopenic purpura}

In patients with immune thrombocytopenic purpura (ITP), there is an accelerated clearance of circulating IgGcoated platelets through $\mathrm{F}_{\mathrm{c}} \gamma$ receptor-bearing macrophages in the spleen and the liver [55]. Syk inhibition should limit platelet destruction in patients with ITP, probably by blocking $\mathrm{F} c \gamma \mathrm{R}$ signaling. Injection of mice with an antibody directed to integrin $\alpha$ IIb leads to profound thrombocytopenia, which is prevented in mice pretreated with R788 [56]. Also, pretreatment with Syk inhibitors prevented anemia in a mouse model of autoimmune hemolytic anemia (AHA) [56]. At the clinical level, treatment of a small number of patients $(n=12)$ suffering from ITP with an R406 led to therapeutic success. Specifically, in 8 patients, the clinical response was sustained, whereas in the remaining 4 , the response was of limited duration. Obviously, larger studies are needed to determine clinical efficacy.

\subsection{Syk inhibitors in intestinal ischemia reperfusion injury} Because hematopoietic cells are involved in the expression of intestinal ischemia-reperfusion injury (IRI), we investigated the ability of R788 to protect mice against 
Table 3. Spleen tyrosine kinase inhibition therapy in allergic inflammatory disease models

\begin{tabular}{|c|c|c|c|c|}
\hline Reference & Drug & Duration & Model & Outcome \\
\hline $\begin{array}{l}\text { Seow } \\
\text { et al. [40] }\end{array}$ & Piceatannol & In vitro & $\begin{array}{l}\text { Ovalbumin-induced anaphylaxis in } \\
\text { guinea pig }\end{array}$ & Prevented histamin and leukotriene release \\
\hline $\begin{array}{l}\text { Guyer } \\
\text { et al. [54] }\end{array}$ & R112 & $\begin{array}{l}\text { One dose, } \\
\text { intranasally }\end{array}$ & $\begin{array}{l}\text { Drug safety study in volunteers with } \\
\text { allergic rhinitis }\end{array}$ & Drug is safe, reduced PGD2, no differences in symptoms \\
\hline $\begin{array}{l}\text { Matsubara } \\
\text { et al. [20] }\end{array}$ & R406 & $\begin{array}{l}10 \text { days, } 5 \mathrm{~mL} / \mathrm{kg}, \\
\text { twice a day, orally }\end{array}$ & $\begin{array}{l}\text { Animal allergic asthma in BALB/C } \\
\text { mice }\end{array}$ & Decreased pulmonary eosinophilia and AHR \\
\hline $\begin{array}{l}\text { Matsubara } \\
\text { et al. [22] }\end{array}$ & R406 & $\begin{array}{l}5 \text { days, } 30 \mathrm{mg} / \mathrm{kg}, \\
\text { twice a day, orally }\end{array}$ & AHR in BALB/c mice & Protected from AHR, eosinophilia, and lymphocytosis \\
\hline $\begin{array}{l}\text { Meltzer } \\
\text { et al. [39] }\end{array}$ & R112 & 2 days, intranasally & Human seasonal allergic rhinitis & Improved global clinical symptoms \\
\hline $\begin{array}{l}\text { Yamamoto } \\
\text { et al. [41] }\end{array}$ & BAY 61-3606 & $\begin{array}{l}21 \text { days, twice a day, } \\
\text { orally }\end{array}$ & $\begin{array}{l}\text { Antigen induced airway } \\
\text { inflammation in rodents. }\end{array}$ & $\begin{array}{l}\text { Suppressed antigen-induced passive cutaneous reaction, } \\
\text { bronchoconstriction, bronchial edema, and airway } \\
\text { inflammation. }\end{array}$ \\
\hline
\end{tabular}

AHR, airway hyper-responsiveness.

IRI [57]. Mice were fed with Syk inhibitor (3 or $5 \mathrm{~g} / \mathrm{kg}$ day) for 6 days before intestinal IRI was performed. We observed that R788 significantly suppressed both local intestinal and remote lung injury. The beneficial effect was associated with reduced IgM and complement 3 deposition to the affected tissues and significant reduction of polymorphonuclear cell infiltration. The value of this study is that it extends the clinical range of the therapeutic value of Syk inhibitors to conditions involving IRI, such as organ transplant and coronary and carotid revascularization.

\subsection{Syk signaling in autoinflammatory disorders}

Recent studies have revealed essential roles for Syk in the inflammasome production of cytosolic Nlrp3 (NLR family pyrin domain-containing 3 ) [58,59]. Syk signaling is important for the production of reactive oxygen species and gene transcription factors important in the expression of proinflammatory factors like IL-1 $\beta$. Pro-IL-1 $\beta$ synthesis is regulated by the Syk-caspase recruitment domain 9 (Syk-Card9) pathway (Figure 6) [58].

Nlrp3 inflammasome has been shown to be involved in monosodium urate (MSU)-mediated activation of monocytes [60]. It was reported that the MSU-triggered inflammatory response requires Nlrp3 and adaptor protein apoptosis-associated speck-like protein containing Card [61]. MSU causes strong Syk tyrosine phosphorylation in human neutrophils, which can be suppressed in the presence of piceatannol [62]. Apparently, Syk is required for MSU-mediated activated protein kinase activation and IL-1 $\beta$ production, and Syk recruitment leads to Card9 activation, which controls pro-IL-1 $\beta$ synthesis (Figure 6) $[58,60,61]$. Card9 has been known to mediate events downstream of Syk in ITAM-mediated activation [63]. These studies have generated a rationale for the use of Syk inhibitors in the treatment of crystal-induced arthritis and other autoinflammatory diseases.

\section{Conclusions and future directions}

Syk, initially recognized as a critical signaling molecule in mast cells and lymphocytes, has been documented to be important in the function of additional cells like platelets, monocytes, macrophages, and osteoclasts. As all of these cells are involved in the instigation and establishment of tissue pathology in autoimmune allergic and autoinflammatory diseases, Syk inhibition has gained significant interest as an important therapeutic tool.

Preclinical evidence argues convincingly that patients suffering from diseases such as RA, SLE, ITP, and AHA and allergic rhinitis stand a good chance to benefit from Syk inhibition. Interestingly, reperfusion injury, which follows ischemia in mice, is greatly suppressed by Syk inhibitors, extending the range of diseases with possible clinical benefit to organ transplantation and revascularization procedures. The clinical experience is limited to patients with RA and ITP. Yet the rapidity of action and the extent of clinical improvement call for further clinical trials.

Obviously, there are serious questions that need attention. Is Syk involved in the function of additional cells? What other kinases or non-kinase molecules are targeted by the available Syk inhibitors? Can medicinal chemistry enable the development of inhibitors that are more specific? The RA trial noted several, albeit manageable, side effects. Do the noted side effects hint at additional unrecognized target molecules affected by the used Syk inhibitor? Do the side effects point to the presence of Syk in additional cells (for example, intestinal epithelial cells). The recorded hypertension in patients treated with the Syk inhibitor needs special consideration.

We believe that now that Syk inhibitors have earned a place in the line of drugs to be further developed for clinical use, effort should be invested to further understand the mechanism of inhibition of Syk enzymatic activity in an effort to derive compounds with increased 


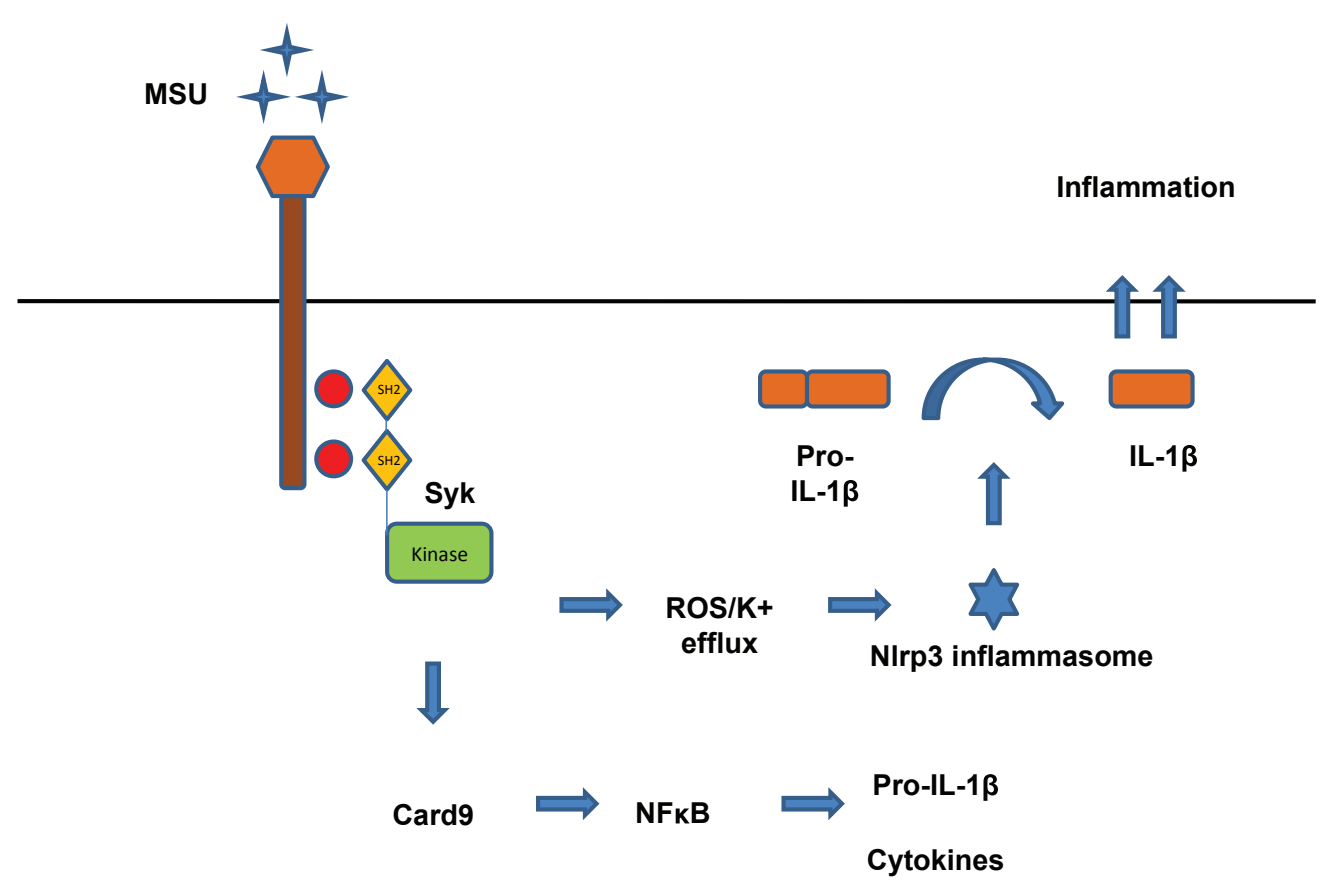

Figure 6. Mechanisms of monosodium urate (MSU)-mediated inflammation and the roles of spleen tyrosine kinase (Syk) and NIrp3. MSU signals activate NIrp3 inflammasome. Syk plays important roles in both pro-IL1 $\beta$ synthesis and NIrp3 activation in response to MSU. Pro-IL1 $\beta$ synthesis occurs through the Syk-Card9 pathway. However, Nlpr3 activation is regulated through a Syk-dependent, mostly Card9-independent mechanism. Card9, caspase recruitment domain 9; IL1 $\beta$, interleukin-1-beta; NF-KB, nuclear factor-kappa-B; NIrp3, NLR family pyrin domaincontaining 3; SH2, Src homology 2.

specificity. The need to further study cells and processes controlled by Syk is exemplified by a recent report in which a Syk-positive myeloid population of cells stimulates lymphangiogenesis in vivo and disruption of Syk among others is associated with inappropriate homing of leukocytes [64].

The RA clinical trial noted a prompt clinical improvement in patients receiving background treatment. Can Syk inhibitors be used in monotherapy? Does prolonged treatment preserve the clinical benefit, and if so, for how long? Does discontinuance of treatment result in a prompt rebound of disease? Do existent erosions heal? The current trend in RA trials remains the parallel administration of biologics in conjunction with MTX to patients who fail MTX. This has led to the development of a number of biologics, many of which belong to the same category. For example, several anti-TNF biologics are already available for the treatment of patients with RA. Should Syk inhibitors attain approval for the treatment of RA, an opportunity may arise (provided that the cost is not too high) to try them in tandem with the biologics or as therapeutic adjuvant to biologics. Should trials in patients with SLE, ITP, AHA, or gout be initiated, a similar and probably longer list of questions should be addressed. The report on the beneficial effect of Syk inhibition in IRI begs for additional preclinical studies to determine the role of Syk inhibition in organ transplant and other models of IRI, such as muscle, heart, and liver.

\section{Abbreviations}

ACR20, American College of Rheumatology 20\% improvement criteria; ACR50, American College of Rheumatology $50 \%$ improvement criteria; ACR70, American College of Rheumatology $70 \%$ improvement criteria; $\mathrm{AHA}$, autoimmune hemolytic anemia; AHR, airway hyper-responsiveness; BCR, B-cell receptor; Card9, caspase recruitment domain 9; CLEC2, C-type lectin-like receptor 2; DAP12, DNAX-activating protein of molecular mass 12 kDa; FLS, fibroblast-like synoviocyte; GPVI, glycoprotein VI; IL, interleukin; IRI, ischemia-reperfusion injury; ITAM, immunoreceptor tyrosine-based activation motif; ITP, immune thrombocytopenic purpura; JAK, Janus kinase 1; JNK, c-Jun N-terminal kinase; MMP, metalloproteinase; MRI, magnetic resonance imaging; MSU, monosodium urate; MTX, methotrexate; NIrp3, NLR family pyrin domain-containing 3; PTK, protein tyrosine kinase; RA, rheumatoid arthritis; SH2, SRC homology 2; SLE, systemic lupus erythematosus; SLP76, SH2 domain-containing leukocyte proteins 76; Syk, spleen tyrosine kinase; TCR, T-cell receptor; TNF, tumor necrosis factor; ZAP70, Z-chain-associated protein kinase of $70-k D a$.

\section{Competing interests}

The authors declare that they have no competing interests.

\section{Author details}

'Division of Rheumatology, Beth Israel Deaconess Medical Center, Harvard Medical School, 330 Brookline Avenue, CLS-928, Boston, MA 02115, USA. 2Division of Rheumatology, Trakya University Medical School, Karaağaç Mh., 22050 Edirne/Edirne Province, Turkey

\section{Acknowledgments}

Work in the GCT lab was supported by PHS R01 Al42269, DoD W81XWH-09-1-0530, and a grant from Rigel Pharmaceuticals (South San Francisco, CA, USA). ONP was supported by a Scientific and Technological Research Council of Turkey (TUBITAK) scholarship. 
Published: 17 December 2010

\section{References}

1. Zhu Y, Herlaar E, Masuda ES, Burleson GR, Nelson AJ, Grossbard EB, Clemens GR: Immunotoxicity assessment for the novel Spleen tyrosine kinase inhibitor R406. Toxicol Appl Pharmacol 2007, 221:68-77.

2. Wong BR, Grossbard EB, Payan DG, Masuda E: Targeting Syk as a treatment for allergic and autoimmune diseases. Expert Opin Investig Drugs 2004, 13:743-762.

3. Tohyama Y, Yamamura H: Protein tyrosine kinase, Syk: a key player in phagocytic cells. J Biochem 2009, 145:267-273.

4. Mocsai A, Ruland J, Tybulewicz LJ: The Syk tyrosine kinase: a crucial player in diverse biological functions. Nat Rev 2010, 10:387-402.

5. Sadak K, Takano T, Yanagi S, Yamamura H: Structure and function of Syk protein-tyrosine kinase. J Biochem 2001, 130:177-186,

6. Berton G, Mocsai A, Lowell A: Src and Syk kinases: key regulators of phagocytic cell activation. Trends Immunol 2005, 26:209-214.

7. Crowley MT, Costello PS, Fitzer-Attas CJ, Turner M, Meng F, Lowell CA Tybulewicz VL, DeFranco AL: A critical role for Syk in signal transduction and phagocytosis mediated by Fcgamma receptors on macrophages. J Exp Med 1997, 186:1027-1039.

8. Turner M, Schweighoffer E, Colucci F, Di Santo JP, Tybulewicz VL: Tyrosine kinase Syk: essential functions for immunoreceptor signalling. Immunol Today 2000, 21:148-154.

9. Turner M, Mee PJ, Costello PS, Williams O, Price AA, Duddy LP, Furlong MT, Geahlen RL, Tybulewicz VL: Perinatal lethality and blocked B-cell development in mice lacking the tyrosine kinase Syk. Nature 1995, 378:298-302.

10. Elder ME, Lin D, Clever J, Chan AC, Hope TJ, Weiss A, Parslow TG: Human severe combined immunodeficiency due to a defect in ZAP-70, a T cell tyrosine kinase. Science 1994, 264:1599-1601.

11. Schweighoffer E, Vanes L, Mathiot A. Nakamura T, Tybulewicz VL: Unexpected requirement for ZAP-70 in pre-B cell development and allelic exclusion. Immunity 2003, 18:523-533.

12. Palacios EH, Weiss A: Distinct roles for Syk and ZAP-70 during early thymocyte development. J Exp Med 2007, 204:1703-1715.

13. Kurosaki T, Hikida M: Tyrosine kinases and their substrates in $B$ lymphocytes. Immunol Rev 2009, 228:132-148.

14. Hong JJ, Yankee TM, Harrison ML, Geahlen RL: Regulation of signaling in $B$ cells through the phosphorylation of Syk on linker region tyrosines. A mechanism for negative signaling by the Lyn tyrosine kinase. J Biol Chem 2002, 277:31703-31714.

15. Ghosh D, Tsokos GC: Spleen tyrosine kinase: an Src family of non-receptor kinase has multiple functions and represents a valuable therapeutic target in the treatment of autoimmune and inflammatory diseases. Autoimmunity 2010, 43:48-55.

16. Kiefer F, Brumell J, Al-Alawi N, Latour S, Cheng A, Veillette A, Grinstein S, Pawson T: The Syk protein kynase is essential for cgamma receptor signaling in macrophages and neutrophils. Mol Cell Biol 1998, 18:4209-4220.

17. Tohyama $\mathrm{Y}$, Yamamura H: Complement-mediated phagocytosis - The role of Syk. IUBMB Life 2006, 58:304-308.

18. Shi Y, Tohyama Y, Kadono T, He J, Miah SM, Hazama R, Tanaka C, Tohyama K, Yamamura H: Protein-tyrosine kinase, Syk is required for pathogen engulfment in complement-mediated phagocytosis. Blood 2006, 107:4554-4562.

19. Luskova P, Draber P: Modulation of the Fcepsilon receptor I signaling by tyrosine kinase inhibitors: search for therapeutic targets of inflammatory and allergy diseases. Curr Pharm Des 2004, 10:1727-1737.

20. Matsubara S, Li G, Takeda K, Loader JE, Pine P, Masuda ES, Miyahara N, Miyahara S, Lucas JJ, Dakhama A, Gelfand EW: Inhibition of spleen tyrosine kinase prevents mast cell activation and airway hyperresponsiveness. Am J Res Crit Care Med 2006, 173:56-63.

21. Costello PS, Turner M, Walters AE, Cunningham CN, Bauer PH, Downward J, Tybulewicz VL: Critical role for the tyrosine kinase Syk in signaling through the high affinity lgE receptor of mast cells. Oncogene 1996, 13:2595-2605.

22. Matsubara S, Koya T, Takeda K, Joetham A, Miyahara N, Pine P, Masuda ES, Swasey $\mathrm{CH}$, Gelfand EW: Syk activation in dendritic cells is essential for airway hyperresponsiveness and inflammation. Am J Respir Cell Mol Biol 2006, 34:426-433.

23. Masuda ES, Schmitz J: Syk inhibitors as treatment for allergic diseases. Pulmon Pharmacol Ther 2008, 21:461-467.
24. Poole A, Gibbins JM, Turner M, van Vugt MJ, van de Winkel JG, Saito T, Tybulewicz VL, Watson SP: The Fc receptor $\gamma$-chain and the tyrosine kinase Syk are essential for activation of mouse platelets by collagen. EMBO 1997, 16:2333-2341.

25. Ozaki Y, Suzuki-Inoue K, Inoue O: Novel interactions in platelet biology: CLEC2/podoplanin and laminin/GPVI. J Thromb Haemost 2009, 7 (Suppl 1):191-194.

26. Boylan B, Gao C, Rathore V, Gill JC, Newman DK, Newman PJ: Identification of FcyRlla as the ITAM-bearing receptor mediating allb $\beta 3$ outside-in integrin signaling in human platelets. Blood 2008, 112:2780-2786.

27. Zou W, Kitaura H, Reeve J, Long F, Tybulewicz VL, Shattil SJ, Ginsberg MH, Ross FP, Teitelbaum SL: Syk, c-Src, the allb $\beta 3$ outside-in integrin signaling in human platelets. J Cell Biol 2007, 176:877-888.

28. Suzuki-Inoue K, Fuller GL, García A, Eble JA, PöhImann S, Inoue O, Gartner TK, Hughan SC, Pearce AC, Laing GD, Theakston RD, Schweighoffer E, Zitzmann N, Morita T, Tybulewicz VL, Ozaki Y, Watson SP: A novel syk-dependent mechanism of platelet activation by the C-type lectin receptor CLEC-2. Blood 2006, 107:542-549.

29. Abhatian F, Guerriero A, Sebzda E, Lu MM, Zhou R, Mocsai A, Myers EE, Huang B, Jackson DG, Ferrari VA, Tybulewicz V, Lowell CA, Lepore JJ, Koretzky GA, Kahn ML: Regulation of blood and lymphatic vascular separation by signaling proteins SLP-76 and Syk. Science 2003, 299:247-251.

30. Mocsai A, Humphrey MB, Van Zieffle JA, Hu Y, Burghardt A, Spusta SC, Majumdar S, Lanier LL, Lowell CA, Nakamura MC: The immunomodulatory adapter proteins DAP12 and Fc receptor gamma chain (FcRgamma) regulate development of functional osteoclasts through the Syk tyrosine kinase. Proc Natl Acad Sci U S A 2004, 101:6158-6163.

31. Koga T, Inui M, Inoue K, Kim S, Suematsu A, Kobayashi E, Iwata T, Ohnishi H, Matozaki T, Kodama T, Taniguchi T, Takayanagi H, Takai T: Costimulatory signals mediated by the ITAM motif cooperate with RANKL for bone homestasis. Nature 2004, 428:758-763.

32. Humphrey BT, Lanier LL, Nakamura MC: Role of ITAM-containing adapter proteins and their receptors in the immune system and bone. Immunol Rev 2005, 208:50-65.

33. Cha HS, Boyle DL, Inoue T, Schoot R, Tak PP: A novel spleen tyrosine kinase inhibitor blocks c-Jun N-terminal kinase-mediated gene expression in synoviocytes. J Pharmacol Exp Ther 2006, 317:571-578.

34. Mun SH, Kim JW, Nah SS, Ko NY, Lee JH, Kim JD, Kim do K, Kim HS, Choi JD, Kim SH, Lee CK, Park SH, Kim BK, Kim HS, Kim YM, Choi WS: Tumor necrosis factor alpha-induced interleukin-32 is positively regulated via the Syk/ protein kinase Cdelta/JNK pathway in rheumatoid synovial fibroblasts. Arthritis Rheum 2009, 60:678-685.

35. Kyttaris V, Tsokos GC: Syk kinase as a treatment target for therapy in autoimmune diseases. Clin Immunol 2007, 124:235-237.

36. Friedberg JW, Sharman J, Sweetenham J, Johnston PB, Vose JM, Lacasce A, Schaefer-Cutillo J, De Vos S, Sinha R, Leonard JP, Cripe LD, Gregory SA, Sterba MP, Lowe AM, Levy R, Shipp MA: Inhibition of Syk with fostamatinib disodium has significant clinical activity in non-Hodgkin lymphoma and chronic lymphocytic leukemia. Blood 2010, 115:2578-2585.

37. Braselmann S, Taylor V, Zhao H, Wang S, Sylvian C, Baloum M, Qu K, Herlaar E, Lau A, Young C, Wong BR, Lowell S, Sun T, Park G, Argade A, Jurcevic S, Pine P, Singh R, Grossbard EB, Payan DG, Masuda ES: R406, an orally available spleen tyrosine kinase inhibitor blocks Fc receptor signaling and reduces immune complex-mediated inflammation. J Pharmacol Exp Ther 2006, 319:998-1008

38. Pine PR, Chang B, Schoettler N, Banquerigo ML, Wang S, Lau A, Zhao F, Grossbard EB, Payan DG, Brahn E: Inflammation and bone erosion are suppressed in models of rheumatoid arthritis following treatment with a novel Syk inhibitor. Clin Immunol 2007, 124:244-257.

39. Meltzer EO, Berkowitz RB, Grossbard EB: An intranasal Syk-kinase inhibito (R112) improves the symptoms of seasonal allergic rhinitis in a park environment. J Allergy Clin Immunol 2005, 115:791-796.

40. Seow CJ, Chue SC, Wong WSF: Piceatannol, A Syk-selective tyrosine kinase inhibitor, attenuated antigen challenge of guinea pig airways in vitro. Eur Pharmacol 2002, 443:189-196.

41. Yamamoto N, Takeshita K, Shicijijo M, Kokubo T, Sato M, Nakashima K, Ishimori M, Nagai H, Li YF, Yura T, Bacon KB: The orally available spleen tyrosine kinase inhibitor 2-[7-(3,4-Dimethhoxyphenyl)-imidazo [1,2-c]pyrimidin-5ylamino] nicotinamide Dihydrochloride (BAY 61-3606) blocks antigeninduced airway inflammation in rodents. J Pharmacol Exp Ther 2003, 306:1174-1181. 
42. Jakus Z, Simon E, Balazs B, Mocsai A: Genetic deficiency of Syk protects mice from autoantibody-induced arthritis. Arthritis Rheum 2010, 62:1899-1910.

43. Schymeinsky J, Sindrilaru A, Frommhold D, Sperandio M, Gerstl R, Then C, Mócsai A, Scharffetter-Kochanek K, Walzog B: The Vav binding site of the non-receptor tyrosine kinase Syk at Tyr 348 is critical for $\beta 2$ integrin (CD11/CD18)-mediated neutrophil migration. Blood 2006, 108:3919-3927.

44. Ravetch JV, Bolland S: IgG Fc receptors. Annu Rev Immuno/ 2001, 19:275-290.

45. Grossbard E, Baluom M, Kivitz AJ: A phase I randomized, double-blind, placebo-controlled, pharmacokinetic study of R788/406 and methotrexate in sixteen patients with rheumatoid arthritis. Arthritis Rheum 2006, 54 (Suppl 9):S408.

46. Weinblatt ME, Kavanaugh A, Burgos-Vagas R, Dikranian AH, Medrano-Ramirez G, Morales-Torres JL, Murphy FT, Musser TK, Straniero N, Vicente-Gonzales, Grossbard E: Treatment of rheumatoid arthritis with a Syk kinase inhibitor: a twelve-week, randomized, placebo-controlled trial. Arthritis Rheum 2008, 58:3309-3318

47. Weinblatt ME, Kavanaugh A, Genovese M, Grossbard E, Magilavy D: Treatment of rheumatoid arthritis (RA) with an oral Syk kinase inhibitor: a 6 month randomized placebo controlled phase $2 \mathrm{~b}$ study in patients with active RA on chronic methotrexate (abstract). N Engl J Med 2010, 363:1313-1320.

48. Genovese M, Kavanaugh A, Peterfy C, Magilavy D: An oral Syk kinase inhibitor in the treatment of rheumatoid arthritis (RA): a 3 month randomized placebo controlled phase 2 study in patients with active RA who had failed biologic agents (abstract). Arthritis Rheum 2009, 60 Suppl:469.

49. Enyedy EJ, Nambiar MP, Liossis SN, Dennis G, Kammer GM, Tsokos GC: Fc epsilon receptor type I gamma chain replaces the deficient $T$ cell receptor zeta chain in T cells of patients with systemic lupus erythematosus. Arthritis Rheum 2001, 44:1114-1121.

50. Bahjat FR, Pine PR, Reitsma A, Cassafer G, Baluom M, Grillo S, Chang B, Zhao FF, Payan DG, Grossbard EB, Daikh DI: An orally bioavailable spleen tyrosine kinase inhibitor delays disease progression and prolongs survival in murine lupus. Arthritis Rheum 2008, 58:1433-1444.

51. Smith J, McDaid JP, Bhangal G, Chawanasuntorapoj R, Masuda ES, Cook HT, Pusey CD, Tam FWK: A spleen tyrosine kinase inhibitor reduces the severity of established glomerulonephritis. J Am Soc Nephrol 2010, 21:231-236.

52. Deng GM, Liu L, Bahjat R, Pine PR, Tsokos GC: Suppression of skin and kidney disease by inhibition of spleen tyrosine kinase in lupus-prone mice. Arthritis Rheum 2010, 62:2086-2092.
53. Plaut M, Valentine MD: Clinical practice. Allergic rhinitis. N Engl J Med 2005, 353:1934-1944.

54. Guyer BJ, Shimamoto SR, Bradhurst AL, Grossbard EB, Dreskin SC, Nelson HS: Mast cell inhibitor R112 is well tolerated and affects prostaglandin D2 but not other mediators, symptoms, or nasal volumes in a nasal challenge model of allergic rhinitis. Allergy Asthma Proc 2006, 27:208-213.

55. Cines DB, Blanchette VS: Immune thrombocytopeic purpura. N Engl J Med 2002, 346:995-1008.

56. Podolanczuk A, Lazarus AH, Crow AR, Grossbard E, Bussel JB: Of mice and men: an open -label pilot study for treatment of immune thrombocytopenic purpura by an inhibitor of Syk. Blood 2009, 113:3154-3160.

57. Pamuk ON, Lapchak PH, Rani P, Pine P, Dalle Luca JJ, Tsokos GC: Spleen tyrosine kinase inhibition prevents tissue damage after ischemiareperfusion. Am J Physiol Gastrointest Liver Physiol 2010, 299:G391-399.

58. Gross O, Poeck H, Bscheider M, Dostert C, Hannesshlager N, Endres S, Hartmann G, Tardivel A, Schweighoffer E, Tybulewicz V, Mocsai A, Tschopp J: Syk kinase signaling couples to the NIpr3 inflammasome for anti-fungal host defence. Nature 2009, 459:433-436.

59. Poeck H, Ruland J: Syk kinase signaling and the Nlpr3 inflammasome in antifungal immunity. J Mol Med 2010, 88:745-752.

60. Shi Y, Mucsi AD, Ng G: Monosodium urate crystals in inflammation and immunity. Immunol Rev 2010, 233:203-217.

61. Martinon F, Petrilli F, Mayor A, Tardivel A, Tschopp J: Gout-associated uricacid crystals activate the NALP3 inflammasome. Nature 2006, 440:237-241.

62. Desaulniers B, Fernandes M, Gilbert C, Bourgoin SG, Naccache PH: Crystalinduced neutrophil activation. VII. Involvement of Syk in the responses to monosodium urate crystals. J Leukoc Bio/ 2001, 70:659-668.

63. Ruland J: CARD9 signaling in the innate immune response. Ann N Y Acad Sci 2008, 1143:35-44.

64. Böhmer R, Neuhaus B, Bühren S, Zhang D, Stehling M, Böck B, Kiefer F: Regulation of developmental lymphangiogenesis by Syk(+) leukocytes. Dev Cell 2010, 18:437-449.

doi:10.1186/ar3198

Cite this article as: Pamuk ON, Tsokos GC: Spleen tyrosine kinase inhibition in the treatment of autoimmune, allergic and autoinflammatory diseases. Arthritis Research \& Therapy 2010, 12:222. 